\title{
Mise en Scène
}

It is the turn of the year 130o. The city of Damascus is filled with a heavy sense of foreboding. Where once the vibrant lights of civilization shone forth to illuminate the surrounding lands, a decidedly somber atmosphere now hung thickly over the deserted marketplaces and alleyways. Most of the city's inhabitants had already fled in horror before the impending cataclysm. The governors and intellectual elite had abandoned camp en masse as well, following their terrified populace south into Palestine, then farther down into Egypt, whose perpetually sunny skies had not yet been darkened by the chilly shadow cast by the gathering menace to the north. The land of Syria was under existential threat. Nowhere in the annals of the ancient metropolis had a more fateful day been recorded; for, perched along the northeast border of the city, ready to swoop down like a pack of vultures at the slightest nod from their redoubtable chief, camped the fearsome hordes of the sons of Genghis Khan.

Some time later, in the dungeon of the citadel at Cairo, quite another battle was being waged. Having been sentenced to one and a half years in prison for propagating allegedly anthropomorphic ideas regarding the nature of God, an energetic, bold, and innately combative scholar and man of religion by the name of Taqī al-Dīn Ibn Taymiyya (d. 728/1328) scarcely seemed fazed by the fact that he was locked behind bars. As long as the prison wards continued to supply him with reams of paper and an ever fresh supply of ink and pens, Ibn Taymiyya could continue to fight a battle infinitely more consequential than the struggle against the Mongols in Syria; for if Damascus, one of the first of the illustrious external citadels of Islam, were to fall to hostile forces, then much was lost indeed. But if the internal citadel of faith itself were overrun, then all was lost, for the stakes here were nothing less than ultimate.

The lines had been drawn long before Ibn Taymiyya's day. Nearly seven centuries had passed since the Prophet of Islam had brought to a chaotic world God's final message to mankind-a revealed Book whose very words were those of God Himself. The message, in its early days, had been clear and pristine. God was al-Haqq, the Ultimate Reality, or the Ultimately Real. He was also al-Khāliq, the Creator of the heavens and earth and of everything they contained. God had also created man and had placed him on the earth to worship his Lord and to work good deeds for as long as he might tarry. Man, inexorably, would one day taste of death, whereafter God would raise him up again, body and soul, to judge him for the sincerity of his faith and the goodness of his works. So was it revealed to them in the Book, and so did they believe in itwith their hearts, as well as with their minds.

(C) CARL SHARIF EL-TOBGUI, 2020 | DOI:10.1163/9789004412866_002

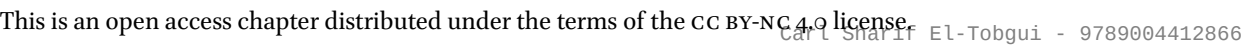


Yet over the centuries, the clear and unencumbered plains of God's Holy Word had slowly but steadily been encroached upon from beyond the horizon, and foreign troops had come to occupy many a Muslim thinker's mind. The mass translation of Greek and Hellenistic medical, scientific-but especially philosophical - texts into Arabic from the time of the Abbasid caliph al-Ma'mūn in the early third/ninth century onward brought a host of new and strange ideas and modes of thinking onto the Muslim intellectual landscape. The works on logic, metaphysics, and other disciplines by Aristotle and various Neoplatonic thinkers fascinated and enticed, yet also discomforted and repelled; for here was a sophisticated, brilliantly exposited view of the world, carefully elaborated over the course of centuries by some of the most brilliant minds the world had ever known. Provocatively, it was a view of the world, a vision of reality, that pretended to far-reaching coherence and comprehensiveness and that presented itself, quite compellingly, as based on, as growing out of, as being derived from nothing less than reason itself.

And what cause was there for worry? For does not the Qurān itself, in numerous passages, beseech its followers to reflect, to ponder, to exploit their God-given intellects, to employ their minds that perchance they might better fathom the purpose of their existence? "A-fa-lā ya'qilün" (Will they not then understand?); "A-fa-lāyatadabbarūn" (Do they not consider [the Qur'ān] with care?); "La'allahum yatafakkarūn" (Perchance they may reflect). ${ }^{3}$

Yet what to make of it were one to comply with God's behest to use one's intellect only to discover, unsettlingly, that what reason has delivered is somehow discordant with what God-Creator of all things, including man and his intellect-has Himself declared in revelation? For the Greeks spoke of man as well. They too spoke of the heavens and the earth, and of God. Reason, Aristotle tells us, perceives that God is a perfect being. Now, all may agree that God is perfect. But reason, Aristotle tells us further, judges that a perfect being must be, among other things, perfectly simple, indivisible, non-composite. So, while revelation may very well seem to predicate certain qualities or attributes of Godsuch as that He is living (hayy), self-subsisting (qayyūm), mighty (jabbār), lovingly kind (wadūd), omniscient ('alìm), all-seeing (bașir), and all-hearing $\left(\operatorname{sam} \imath^{\tau}\right)$ —reason, for its part, avers that God cannot in reality possess any such attributes, for then He would no longer be perfectly simple, as reason requires

1 Q. $Y \bar{a} \operatorname{Sin} 36: 68$. All translations in this work, whether from Arabic or from European languages, including translations of the Qurān and hadìth, are mine except where otherwise indicated.

2 Q. al-Nisä' 4:82 and Muhammad 47:24. (Trans. 'Abdullāh Yūsuf 'Alī, The Meaning of the Holy Qurān. Hereafter Yusuf Ali.)

3 Q. al-A'räf 7:176, al-Nahl 16:44, and al-Hashr 59:21. 
Him to be, but composite; that is, He would be "composed" of His uniquely indivisible essence and His alleged attributes or qualities. Similarly, we are told, the dictates of sound reason affirm that God cannot be held to have knowledge of any particular, individual, instantiated thing in the world, as all such things are impermanent, springing into existence one day only to succumb to their demise the next. It follows by rational inference, therefore, that God cannot be held to know any such ephemera, for to know them would imply a relational change (and therefore an imperfection) in His knowledge. But, does not God Himself say in revelation, "Wa-mā tasquțu min waraqatin illā ya lamuhä" (And not a leaf falls but that He knows it)? ${ }^{4}$ Indeed, He does. And so the lines are drawn, and the battle is on.

4 Q. al-An'ām 6:59. 